\title{
JOURNAL.RU
}

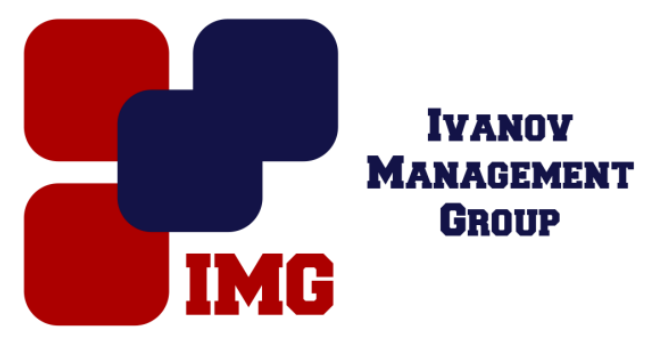

Лященко М.H.

Оренбургский государственный университет

Оренбург, Россия

doi: 10.18411/1j-31-07-2017-01

idsp 000001:1j-31-07-2017-01

\section{Одиночество в социальных сетях в условиях глобализирующегося общества}

\section{Аннотация}

В работе рассмотрено одиночество в социальных сетях, ставшими неотъемлемой характеристикой глобализирующегося общества. Автором подчеркивается мысль, что, несмотря на положительный эффект, привносимый социальными сетями и удовлетворяющими человека как социальное существо, во многом создают благоприятные условия для «вызревания» одиночества.

Ключевые слова: одиночество, социальные сети, глобализирующееся общество, капитализм.

Непрерывное наращивание производственных сил, рост автоматизации, и вследствие этого увеличение объемов потребляемых унифицированных материальных и «духовных» благ, а также смена инновационной техники и технологии, порождают проблему взаимоотношений между поколениями, выражающаяся в ситуации когда «опыт старших, как основа для социализации новых поколений, теряет свою прежнюю силу и способность, переходить в разряд проблематичных» [1, С. 161]. Вследствие этого образуются ценностносмысловые разрывы между поколениями, растет непонимание и равнодушие к старшему поколению со стороны младшего. По верному замечанию Н.В. Попковой: «Очередная технологическая инновация может обесценить его (индивида) знания и умения. Ненадежность долгосрочных планов из производственной области распространяется на всю человеческую жизнь» [2, С. 44]. В таком быстроменяющемся информационно-технологическом мире никто 
не может быть надежно защищенным и уверенным в завтрашнем дне. Планирование будущего становится тщетным и бессмысленным занятием, а социальная реальность чуждой и неестественной. Таким образом, в современном мире по причине временности и неустойчивости социально-культурных связей и потере контроля человека над своей и общественной жизнью, обрывается социокультурная преемственность, интегрирующая и скрепляющая поколения на основе включения индивидов в единую социально-культурную жизнь.

Одной из характеристик глобализирующего общества является его гомогенность, анономизация и атомарность, на смену внутренним, прочным связям приходят внешние анонимные социальные связи, которые совершенно не подкреплены изнутри - ценностно-духовными связями, делающих их крепче и плотнее. Особенностью таких внешних анонимных связей и образующихся на их основе коллективов является отсутствие единой системы духовнонравственных ценностей, которая бы обеспечивала живую, органическую связь между индивидами, и между ними и общественными институтами.

Массовое общество напичкивает человека все более всесторонними, формальными, безжизненными контактами и связями (Интернет, телефонная связь и т.д.), вводя его в безжизненное пространство анонимных индивидов, боящихся раскрыться и проявляющих свои низшие, извращенные человеческие стороны благодаря анонимности, которую обеспечиваю новые информационнотехнические средства коммуникации. Притягательность социальных сетей заключает в том, что они выстроены на основе социальной и диалогичной природы человека, но только взамен живому общению и диалогу, предлагается суррогатное, анонимное общение, которое должно было бы стать только предпосылкой для перехода к более высшим уровням общения, а на деле совсем наоборот - оно для многих полностью вымещает живое общение с его чувственно-эмоциональной окраской и духовной конфликтностью.

Кроме этого, информативно-коммуникационные сети обеспечивают условия быстрой связи между участниками капиталистического рынка, интенсификацию финансовых операций на биржевых рынках, и в то же время удобство и скорость в обмене рабочей информацией. Все эти факторы отвечают требованием возрастающего непрерывного экономического динамизма. Однако, их влияние на формирование одиночество опосредованно, в связи с уже имеющимися разрушительными процессами на всех участках ценностносмыслового пространства в глобализирующемся обществе. Зачастую уже одинокий человек прибегает к таким контактом, а не они его делают таковым. 
Характерной особенностью такой коммуникации является то, что за ней, на наш взгляд, скрывается удовлетворение какого-либо личного интереса индивида, прибегающего к анонимным и виртуальным связям. Тем не менее, не следует отрицать их негативного влияние в замещении живого, открытого и межличного общения между индивидами, которое является основой взаимоотношений между индивидами, нарушении целостности внутреннего мира человека и деградации его как личности, включающегося зачастую в связи, не заполненные каким-либо ценностным или смысловым содержанием. Между тем, чтобы избежать одиночества необходимо человеку быть активным членом общества или какой-либо реальной социальной группы, участники которой должны являться не только близкими ему по духу, но и стать частью его внутренней «вселенной», за которых он нес бы ответственность.

Опасность сегодняшнего времени заключается еще в том, что подрастающее поколение чрезмерно пребывает в интернет-сообществах, заменяя живое общение, отрываясь от социальной реальности, закрываясь в виртуальном, иллюзорном мире, деформируя свою социальную сущность до такой степени, что виртуальные контакты полностью заменяют живое непосредственное общение [3, С. 59], что приводит к отучению навыков общения с другими людьми и их социальному самозамыканию. Но это обстоятельство может и не означать, что человек, переживает одиночество. Это произойдет, скорее всего, на стадии осознания им иллюзорности, ложности и бессмысленности мира, в котором он пребывает и недосягаемости подлинного уже отдаленного мира, а до тех пор он не будет ощущать своего одиночества, пребывая в фазе «пред-одиночества», в особенности это касается тех людей, которые причисляются к категории интернет зависимых.

Таким образом, социальные сети как необходимый и неотъемлемый элемент социальной структуры глобализирующего общества оказывает как положительное, так и негативное влияние на взаимоотношения между индивидами. Негативное влияние проявляется в том, что социальные сети заменяют подлинную и органическую коммуникацию между индивидами, наполняя их формальными и безжизненными, порой виртуальными контактами и связями. Последний аспект, сегодня, является одним из факторов, способствующим проявлению одиночества. 
1. Салихов, Г.Г. Человек эпохи глобализации / Г.Г. Салихов. - М.: Наука, 2008. -560 с.

2. Попкова, Н.В. Антропологический кризис и его философский анализ / Н.В. Попкова // Социально-гуманитарные исследования в БГТУ: сб. ст. / под общ. ред. А.Ф. Степанищева. - Брянск: БГТУ, 2009. - С. 36-55.

3. Еляков, А.Д. Благо и зло: жгучий парадокс Интернета / А.Д. Еляков // Философия и общество. - 2011. - №2. - С. 58-77 